\title{
Oncological profile among children of a rural Medical College of West Bengal, Eastern India
}

\author{
Sanjay Halder ${ }^{1}$, Sanjana Samanta ${ }^{2}$, Dipak Patra ${ }^{3}$, Ramakrishna Mondal ${ }^{4}$, \\ Asok Kumar Datta ${ }^{5}$ \\ ${ }^{1}$ RMO cum Clinical Tutor, Murshidabad Medical College, ${ }^{2}$ Junior Resident, N.R.S. Medical College, ${ }^{3}$ Assistant \\ professor, Murshidabad Medical College, ${ }^{4}$ Associate Professor, Bankura Medical College, ${ }^{5}$ Asssociate professor \\ Bankura Medical College.
}

\begin{abstract}
The paediatric population (0-14 years of age) constitutes $32.4 \%$ of the total population of India . Paediatric neoplasms constituted 3.7-4\% of all the cancers. More than $10 \%$ of all deaths in children below 15 years of age are caused by malignant diseases in developed countries. An attempt is made to describe the pattern of pediatric cancer seen at Rural Medical College, Bankura, West Bengal. Total number of patients registered during this 3.5 years period was 70 . The most common malignancy in children was leukaemia, which constituted $60 \%$ of the cancer load, followed by lymphomas- $17.1 \%$, CNS neoplasms $-5.7 \%$, Renal tumors(including Wilms' tumour)- $5.7 \%$, neuroblastomas- $4.3 \%$, germ cell tumours- $4.3 \%$, retinoblastomas$1.4 \%$ and hepatoblastoma $-1.4 \%$ in the decreasing order of their frequencies.
\end{abstract}

\section{Introduction}

Cancer in children is an emerging major childhood killer. The paediatric population (0-14 years of age) constitutes $32.4 \%$ of the total population of India [1]. Paediatric neoplasms constituted 3.7-4\% of all the cancers [2]. More than $10 \%$ of all deaths in children below 15 years of age are caused by malignant diseases in developed countries (3). In the developing world, childhood cancers are yet to be recognized as a major pediatric illness due to several other competing causes of death like diarrheal illness and respiratory illness.

However, due to considerable reduction in infant and child mortality rates experienced in a few developing countries, it is emerging as a distinct entity to be dealt upon. An attempt is made in this paper to describe the pattern of pediatric cancer seen at Rural Medical College, Bankura, and West Bengal which is likely to more often reflect the pattern in the community. In the absence of reliable population registration, hospital statistics in developing countries provide the only available window to observe the disease pattern in the community.

\section{Materials and Methods}

All cases of malignant disease in children registered between January 2009 and June2012 were included in the study. The case records pertaining to the age group 0-12 years were analyzed to find out the descriptive clinical profile of these patients.

Histological diagnosis was confirmed by our pathologist in all cases except for surgically inaccessible intracranial tumors. Histological classification system used was the one proposed by International Classification of Childhood Cancer [4] which was basically based on the ICD-0-2 (International Classification of Diseases for Oncology) and modification of Birch and Marsden (1987) classification by Kramarova and Stiller (1996). [5]

\section{Results}

Total number of patients registered during this 3.5 years period was 70 . The most common malignancy in children was leukaemia, which constituted $60 \%$ of the cancer load, followed by lymphomas- $17.1 \%$, CNS neoplasms -5.7\%, Renal tumors(including Wilms' tumour)- 5.7\% , neuroblastomas- $4.3 \%$, germ cell tumours$4.3 \%$, retinoblastomas- $1.4 \%$ and hepatoblastoma $-1.4 \%$ in the decreasing order of their frequencies . Figure 1 shows the distribution of cases according to the classification scheme recommended by International classification of Childhood Cancer [4] 


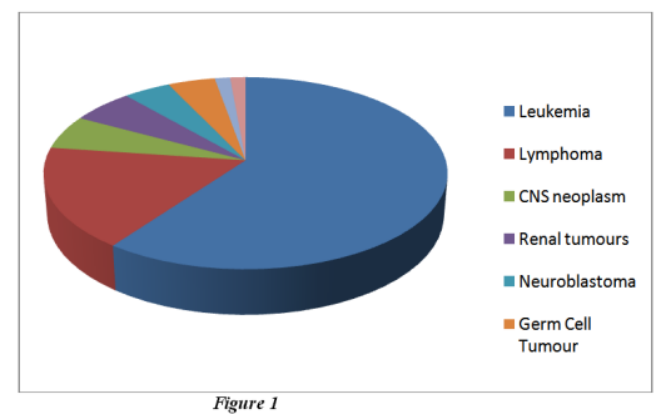

The commonest paediatric malignancy was leukemia (42 cases) accounting for $60 \%$ of all cancers. Acute lymphoblastic leukemia (ALL) represented the commonest form of malignancy among all hematological malignancy. Among these 42 cases of acute leukemia, 36 cases $(85.7 \%)$ were ALL \& 4 cases $(9.5 \%)$ were Acute myeloid leukaemia (AML) (ALL: AML - 9: 1). One case was diagnosed in preleukemic phase \& another case as JCML. The diagnosis was based on clinical pictures, peripheral blood picture \& bone marrow morphology. Cytochemical study was not possible in every case due to financial constraints.

ALL cases had an age range of 0.45-10 years (average 4.4 years). AML patients had an age range of 1.5-8years (average 5.37 years). Among the different symptoms, fever $(73.8 \%)$ was commonest followed by pallor $(66.6 \%)$. Hepatomegaly $(57.1 \%)$, splenomegaly $(54.8 \%)$ and lymphadenopathy $(52.3 \%)$ were the frequent signs at the time of presentation (Table 1).

Bleeding manifestation was seen in the form of petechiae $(21.4 \%)$ and epistaxis $14.2 \%$ cases at their initial presentation. Three cases (7.1\%) of leukemia presented with joint pain (one or multiple), Other rare presentation was limping, ascites, pedal oedema and weakness. Few associated finding was café-a lait spot, congenital heart disease and downs syndrome.

Lymphomas were seen in about $17 \%$ of cases of which non-Hodgkin's lymphoma (NHL) was more common (58.3\%). Most of the NHLs were high grade and diffuse. Most of them presented with lymphadenopathy(71.4\%) either localised $(40 \%)$ or generalised(60\%) followed by paraplegia $(14.2 \%)$ and respiratory distress (14.2\%). The most common histological subtype of Hodgkins disease was mixed cellularity. Cervical lymphadenopathy were noted in all cases of hodgkins lymphoma. Childhood lymphoma had age range 5 to 10.5 years with mean age of presentation was 7.8 yrs.

CNS tumor was found in $5.7 \%$ cases \& includes astrocytoma, glioma and choroid plexus papilloma. Seizures, ataxia and respiratory distress were the presenting features.

Neuroblastoma (sympathetic nervous system tumor) was found $4.3 \%$ cases. Spastic paraplegia and generalised weakness were the presenting features.

Among renal tumors wilms' tumor was the predominant one. Wilms tumors were seen in about $4.3 \%$ cases \& that of the renal cell sarcoma in $1.4 \%$ cases. Abdominal mass, abdominal pain and hematuria were the complaints at their initial presentation. It has age range $2.5 \mathrm{yrs}-6 \mathrm{yrs}$ with a mean age of $3.5 \mathrm{yrs}$.

Germ cell tumors occupied $4.3 \%$ of total cases presenting with lower abdominal pain and swelling with age range $3-6.5 y r s$ with a mean age of $4.4 y r s$.It was most common among girls.

Retinoblastoma occuping $1.4 \%$ of total malignancy presented very late with a fungating ocular mass.

One case of Hepatoblastoma (1.4\% of total cases) who presented at 2years of age with abdominal distension was diagnosed during our study period.

No malignant bone tumor or soft tissue sarcoma were reported or diagnosed during our study period.

In general, the malignancies were more in males (male:female 1.4:1) and $45.7 \%$ of all cancers were seen in children below 5 years of age.

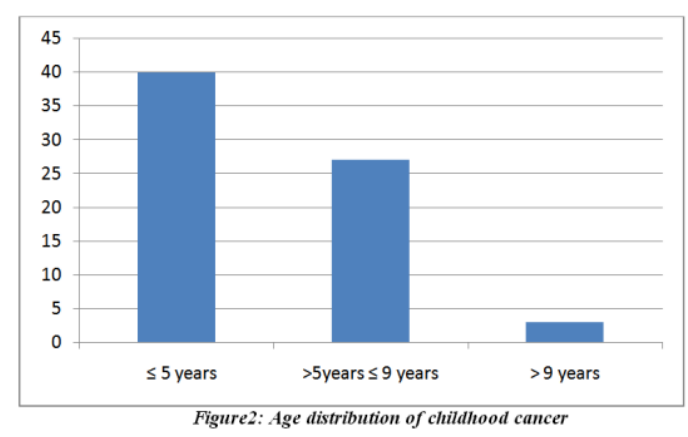

Figure2: Age distribution of childhood cancer 


\section{Discussion}

The general pattern of pediatric tumors in our center seems to resemble the distribution of pediatric cancers reported from other countries [10-13].Marked differences were found in the age distribution of various cancers. The frequency of ALL, neuroblastoma, Wilm's tumor, retinoblastoma and hepatoblastoma were strikingly more in children younger than 5 years of age. An increased frequency with age was seen in nonHodgkin's lymphoma, Hodgkin disease. The early onset and the embryonal nature of many pediatric tumors suggest a prenatal origin.

In all the paediatric age groups, leukaemia was found to be the most common type of cancer, which was similar to that which was reported by most of other literatures [2, 8, 9,13,18]. Lymphoma were the second most common malignancies.

Most of the studies including the present study revealed a male predominance.

Table 1: Comparison of male: female ratio with other Study

\begin{tabular}{|l|l|}
\hline Studies & $\mathrm{M} / \mathrm{F}$ Ratio \\
\hline 1. Jussawalla et al., Bombay, 1988 [6] & 1.7 \\
\hline 2. Mangal et al., Rajasthan, 1991 [7] & 1 \\
& \\
\hline 3. Das et al., West Bengal, 1994 [8] & 2 \\
\hline 4. Nandakumar et al., Bangalore, 1996 [9] & 1.8 \\
\hline 5. Grovas et al., Ncdb, UU, 1997 [10] & 1.2 \\
\hline 6. Martin et al., Cuba, 1997 [11] & 0.98 \\
\hline 7. Gutierrez et al., Mexico, 1997 [12] & 1.6 \\
\hline 8. Ocana et al. Mexico, 2004 [13] & 1.1 \\
\hline 9. Bryan et al., Vellore, 2011 [14] & 4 \\
\hline 10. Bryan et al., Usa, 2011 [14] & 1.10 \\
\hline 11. Bhalodia et al., Gujarat, 2011 [15] & 1.3 \\
\hline 12. Present Study, 2012 & 1.4 \\
\hline
\end{tabular}

The male predominance in our country could be due to the extra attention which is given to the male child as a result of cultural factors [6]. Environmental factors like exposure to carcinogens at work or smoking habits may be contributing to excess of cancer in adult males, but such an explanation cannot account for the excess of cases seen in male children. According to Kusumakumary et al, male predominance is a salient feature of many childhood tumours. The male excess is particularly marked in the neoplasms of lymphoid origin, possibly due to the genetic differences in the immune function. However, the female excess which was seen in germ cell tumours may be due to the earlier development of ovarian tumours than the testicular tumours [2].

Table 2 Comparison of Incidence of Pediatric malignancies with studies in India

\begin{tabular}{|l|l|l|l|l|l|l|l|l|}
\hline Types of cancer & $\begin{array}{l}\text { Bombay } \\
(1988) \\
{[16]}\end{array}$ & $\begin{array}{l}\text { Rajasthan } \\
(1991)[7]\end{array}$ & $\begin{array}{l}\text { West } \\
\text { Bengal } \\
(1994) \\
{[8]}\end{array}$ & $\begin{array}{l}\text { Bangalore } \\
(1996)[9]\end{array}$ & $\begin{array}{l}\text { Kerala } \\
(2000)[2]\end{array}$ & $\begin{array}{l}\text { Gujarat } \\
(2011) \\
{[15]}\end{array}$ & $\begin{array}{l}\text { Orissa, } \\
(2007) \\
(17)\end{array}$ & $\begin{array}{l}\text { Present } \\
\text { study } \\
\text { West } \\
\text { bengal }\end{array}$ \\
\hline Leukemia & 31.8 & 26 & 36 & 29 & 30 & 44.18 & 45.5 & 60 \\
\hline Lymphoma & 10.7 & 32 & 9.5 & 19 & 10 & 16.27 & 8.2 & 17.1 \\
\hline CNS neoplasm & 12.2 & 1.6 & & 13.2 & 19.3 & 6.97 & 3.6 & 5.7 \\
\hline Neuroblastoma & & 13 & & 4.7 & 5.1 & 6.97 & 4.5 & 4.3 \\
\hline Retinoblastoma & 6.3 & 1.2 & 32.6 & 3.8 & 4.5 & & 5.5 & 1.4 \\
\hline Renal tumors & 6.1 & 16 & 4.2 & 5.1 & 5.4 & 9.30 & 4.5 & 5.7 \\
\hline Hepatic tumors & & & & 0.9 & & & 0.9 & 1.4 \\
\hline $\begin{array}{l}\text { Malignant bone } \\
\text { tumor }\end{array}$ & 8.9 & & 5.8 & 3.4 & 5.4 & 2.32 & 10 & \\
\hline $\begin{array}{l}\text { Soft tissue } \\
\text { sarcoma }\end{array}$ & & & 5.2 & 4.7 & 6.6 & 2.32 & 11.8 & \\
\hline Germ cell tumor & & 5.7 & 5.2 & 2.9 & & & & 4.9 \\
\hline Carcinoma & & & 1.5 & 4.8 & 13.8 & 11.67 & & 4.3 \\
\hline Miscellaneous & 15.3 & 4.5 & 5.5 & & & \\
\hline
\end{tabular}

Table 3Comparison of incidence of Pediatric malignancies with studies outside India

\begin{tabular}{|l|l|l|l|l|l|l|}
\hline $\begin{array}{l}\text { Types } \\
\text { cancer }\end{array}$ & $\begin{array}{l}\text { CUBA,1997 } \\
(11)\end{array}$ & $\begin{array}{l}\text { Mexico 1997 } \\
(12)\end{array}$ & $\begin{array}{l}\text { SEER } \\
1999(19)\end{array}$ & $\begin{array}{l}\text { MEXICO 2004 } \\
(13)\end{array}$ & $\begin{array}{l}\text { Present study } \\
\text { India,2012 }\end{array}$ \\
\hline Leukemia & 29.6 & 31.2 & 39.2 & 31.5 & 36.1 & 60 \\
\hline Lymphoma & 11.2 & 18.4 & 17.6 & 10.7 & 11.4 & 17.1 \\
\hline CNS neoplasm & 23.6 & 15.2 & 12.6 & 20.2 & 11.6 & 5.7 \\
\hline Neuroblastoma & 6.0 & 7 & 3.0 & 7.8 & 2.3 & 4.3 \\
\hline Retinoblastoma & 1.8 & 2.5 & 2.5 & 3.1 & 4.3 & 1.4 \\
\hline Renal tumors & 6.6 & 4.5 & 6.3 & 4.2 & 5.7 \\
\hline
\end{tabular}


Oncological profile among children of a rural Medical College of West Bengal, Eastern India

\begin{tabular}{|l|l|l|l|l|l|l|}
\hline $\begin{array}{l}\text { Hepatic } \\
\text { Tumors }\end{array}$ & 1.2 & 1.4 & 0.5 & 1.3 & 1.8 & 1.4 \\
\hline $\begin{array}{l}\text { Malignant } \\
\text { bone tumors }\end{array}$ & 5.1 & 5.5 & 4.5 & 4.5 & 5.7 & \\
\hline $\begin{array}{l}\text { Soft tissue } \\
\text { sarcoma }\end{array}$ & 7.4 & 6 & 5.0 & 7.0 & 5.2 & \\
\hline $\begin{array}{l}\text { Germ cell } \\
\text { tumors }\end{array}$ & 2.8 & 2 & 8.6 & 3.5 & 6.5 & 4.3 \\
\hline Carcinoma & 1.6 & 3.7 & 1.5 & 3.5 & 1.1 & \\
\hline Miscellaneous & 2.9 & 2.1 & & 0.5 & & \\
\hline
\end{tabular}

Comparison of the relative frequencies of childhood cancer with those of other studies in India and outside India has been depicted in Table- 2 and Table- 3 respectively.

Leukaemia was the commonest of the childhood cancers in most of the studies from India and also from abroad. The incidence of lymphoma in the present study was $17.1 \%$, which was comparable to that in other studies, which had an approximately $10 \%$ incidence $[2,8,18,19]$

The percentage of the CNS neoplasms in present study was 3.64\%, which was comparable to the finding of Mangal et al, and Niharika pattnaik et al study but a higher incidence was observed in other studies from India and other countries [7]. This is probably due to the inadequate facility for paediatric neurosurgery at our hospital.

The incidence of neuroblastoma, nephroblastoma, germ cell tumours and hepatoblastoma in the present study was comparable with that of other studies Table-2 and 3.

The incidence of retinoblastoma in present study (1.4\%) was in accordance with Mangal and Miglani study but slightly lower from the value observed by Jussawalla et al., (6.3\%), Nandakumar et al (3.8\%), Kusumakumary et al $(4.5 \%)$ and Ocana et al., who found a $4.3 \%$ incidence $[2,9,13,16]$. Retinoblastoma runs in families and a higher incidence was associated with older paternal age, which increased the frequency of the mutation [8]. Most of the studies from outside India showed a lower frequency of retinoblastoma.

Most of the other studies, where malignant bone tumor was found to vary from $2.32 \%-5.8 \%$ [16], no case was diagnosed or reported in our department during our study period. It may be due to low incidence as seen in Mangal et study or it may be due to lack of awareness regarding necessity of early consultation of a relatively less important organ problem or spending a long time for ayurvedic or kabiraji treatment.

\section{Conclusion}

At present we have no population based statistical data on childhood cancer. It is, therefore, not possible to assess the magnitude of the cancer problem in our country according to standard statistical methods. Accurate incidence of data is important in the planning and evaluation of clinical trials. Establishment of committed pediatric cancer registries in India will certainly contribute to useful clinical epidemiological research. Population based statistical data on childhood cancer will help in assessing the magnitude of the cancer problem in our country.

From the viewpoint of cancer control, particularly in the context of developing countries like India, there is a need to detect cancers at an early, curable stage of the disease. Their late presentations may be due to many factors which include lack of awareness and socioeconomic conditions, to some extent. In general, it is important to remember that when a child is affected by cancer, it creates a deep emotional impact on the entire family and they need special care and education.

\section{References}

[1] Park K. Test book of Preventive and Social Medicine, $19^{\text {th }}$ ed. Banarsidas Bhanot, Jabalpur; $2007 ; 382$.

[2] Kusumakumary P, Jacob R, Jothirmayi R, Nair MK. Profile of paediatric malignancies: A ten year study. Indian Pediatrics 2000; 37: 1234-38

[3] Silverberg E, Laura JA. Cancer statistics, CA Cancer J Clin 1998; 38: 5-22.

[4] Kramarova E, Stiller CA . The International Classification of Childhood Cancer. International Journal of Cancer 1996; 68:759-65.

[5] Birch JM, Marsden HB . A classification scheme for childhood cancer. International Journal of Cancer 1987; 40:620-24.

[6] Jussawalla DJ, Yeole BB. Childhood cancer in Greater Bombay. Indian Journal of Cancer 1988; 25: 197-206.

[7] Mangal N, Miglani N. The pattern of paediatric malignancies is Rajasthan. Indian Pediatrics 1991; 28: 1517-18.

[8] Das S, Chakraborty AK, Mukharjee K, Kundu BK, et al. The profile of malignant lesions amongst children in north Bengal. Indian Paediatrics 1994; 31: 1281-85.

[9] Nandakumar A, Anantha N, Appaji L, Swamy K, et al. Descriptive epidemiology of childhood cancers in Bangalore, India. Cancer Causes and Control 1996; 7: 405-10.

[10] Grovas A, Fremgen A, Rauck A, Ruymann FB, et al. The National Cancer Data Base Report on the patterns of childhood cancers in the United States. Cancer 1997; 80(12); 2321-32.

[11] Martin AA, Alert JA, Reno JS, Lonchong M, et al. Incidence of childhood cancer in Cuba (1986-1990). International Journal Cancer 1997;72: 551-55.

[12] Gutierrez AF, Martinez AN, Garcia MR, Morales MEZ, et al. Incidence of malignant neoplasms in children who attend social security hospitals in Mexico City. Med Paediar. Oncology 1997; 29: 208-12. 
[13] Ocana SJ, Miranda GG, Arangure JMM, Madias MER, et al. The frequency of cancer in children who reside in Mexico City and who are treated in the hospitals of the Instituto Mexicano del Segurosocial (1996-2001). BMC Cancer 2004; 4: 50-58.

[14] Bryan EH, Kenneth F, Barbara N, Meenakshi S. Paediatric solid malignant neoplasms: A comparative analysis. Indian Journal of Pathology and Microbiology 2011; 54 (3): 514-19.

[15] Balhodia JN, Paterl MM. The profile of paediatric malignancy: A three year study. National J. of Community Medicine 2011; 2(1):24-27.

[16] Arora R.S., Eden TOB, Kapoor G. Epidemiology of childhood cancer in India. Indian J. of Cancer 2009; 46 (4): 264-73.

[17] Pattnaik Niharika, Khan MobarakAhemad, Rao Epari Sanjeeva, Rao B. Rama Mohan. Paediatric Malignancies. Journal of Clinical and Diagnostic Research. 2012 May (Suppl-2), Vol-6(4): 674-677

[18] Chaudhuri K, Sinha A, Hati GC, Karmakar R, et al. Childhood malignancies at the BS Medical College: a ten year study: Indian J. Pathol Microbiol 2003; 46(2): 194-96.

[19] Ries LAG, Smith MA, Gurney JG, Linct M, et al. Cancer incidence and survival among children and adolescents: the United States SEER Programme 1975-99, Nat. Cancer Institute, SEER Program. NIH Pub. No. 99-4646. Bethesda, MD, 1999. 